\title{
Large US bank takeovers in 2008: performance and implications
}

\author{
Guoxiang Song \\ Accounting and Finance, University of Greenwich, London, UK
}

\begin{abstract}
Purpose - Because systemically important banks' takeovers in the US were expected to contain the 2008 global financial crisis (GFC) but were found to have imposed large cost on shareholders, this paper examines the effectiveness of these acquisitions during the GFC and investigates what went wrong with the market for corporate control of large banks.

Design/methodology/approach - This paper presents a model of the disciplinary takeover based on the efficient market hypothesis which provides appropriate measures for it to examine the financial performance of acquiring banks after takeover.

Findings - The results indicate that the takeover market for large banks was ineffective in two aspects: the market did not distinguish strong banks from weak banks before the crisis and acquirers performed worse after takeover. Such ineffectiveness reflects the fundamental deficiencies of large bank takeovers arising from some key distinguishing characteristics of large banks.

Research limitations/implications - The sample size of systemically important banks' takeovers is small so large-sample standard statistical inferences cannot be used.

Practical implications - The deficiencies of large bank takeovers need to be rectified in order to aid in resolving future crises.

Originality/value - This paper provides rare and detailed insight based on case studies of large US bank takeovers during the GFC.

Keywords Corporate control, Disciplinary takeover, Systemically important banks, Global financial crisis, Information asymmetry, Pro-cyclicality

Paper type Research paper
\end{abstract}

\section{Introduction}

In the US and UK market-based financial systems, takeovers perform as the market for corporate control because they transfer controls of weak firms to strong firms. They are the principal form of management discipline which enhances the accountability of management and the board to shareholders. However, some takeovers ended up as a disaster. For example, RBS's acquisition of ABN AMRO was a significant contributor to RBS's failure in 2008 (FSA, 2011). Moreover, "most takeovers occur only after a prolonged period of corporate decline" (Porter, 1992, p. 81). In particular, systematically important banks' takeovers in the US that were expected to contain the 2008 global financial crisis (GFC) are found to have imposed large cost on shareholders (Financial Commission, 2011; Protess, 2012). This paper will examine the financial performance of these large US banks' acquisitions during the GFC and investigate what went wrong with the market for corporate control for large banks.

(C) Guoxiang Song. Published in Journal of Capital Markets Studies. Published by Emerald Publishing Limited. This article is published under the Creative Commons Attribution (CC BY 4.0) license. Anyone may reproduce, distribute, translate and create derivative works of this article (for both commercial and non-commercial purposes), subject to full attribution to the original publication and authors. The full terms of this license may be seen at http://creativecommons.org/licences/by/4.0/legalcode

The author is grateful to the Professor Geoff Meeks for his advice. The author also thanks Professor Aleksandar Stojanovic, Professor Michael Jones and participants at the 11th International Risk Management Conference for their helpful comments. The author thanks Professor Guler Aras and two anonymous referees for their very detailed and helpful comments and suggestions.

Received 19 June 2021 Revised 16 September 2021 Accepted 8 October 2021

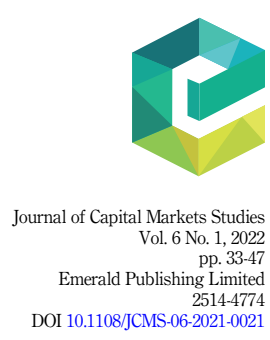


JCMS 6,1

The weakening function of large bank takeovers in the US is shown in two aspects. First, takeovers of large weak banks were too late. During the GFC, the acquired banks in the US were either nearly bankrupt or bankrupt (Macskasi, 2016). For example, JP Morgan Chase acquired Bear Stearns with government support when Bear Stearns was near collapse in March 2008, and JP Morgan Chase acquired the banking assets of Washington Mutual after Washington Mutual went bankrupt in September 2008 which was the biggest bank failure in the US.

Second, there are few large bank takeovers in recent years. Since the GFC, mergers involving large banks with assets of more than $\$ 10$ billion in the US are rare (Kowalik et al., 2015; Macskasi, 2016). The $\$ 28$ billion acquisition of SunTrust by BB\&T in 2019 was the only mega-transaction in the US banking industry in a decade.

Such deterioration suggests that takeovers may not be relied on as one of the primary capital market solutions to large banks' failure in future crises. However, the failure of large banks can generate significant cost for shareholders and other stakeholders, especially during financial crises. Moreover, there is evidence of flight to quality among large financial institutions during the financial crisis of 2008-2009 (Inci et al., 2014). Therefore, it is important to investigate the effectiveness of large bank takeovers during the GFC.

The paper contributes to the literature by presenting a general model of the disciplinary takeover based on the efficient market hypothesis (EMH). The model is different from popular pure financial play models, and it proposes how to use appropriate financial performance measures rather than some popular measures used in the literature to evaluate the performance of acquirers. The paper analyzes the effectiveness of large bank takeovers in terms of both operating performance and stock market performance based on this model by investigating six private takeover deals of systematically important US banks during the GFC. These deals are selected because they have significant implications for global financial stability - they were expected by the US government to save weak banks to contain the GFC and the acquirers are global systematically important banks (FSB, 2020).

The paper finds that large bank takeovers in the US during the GFC were not effective. This is because the market could not distinguish strong banks from weak banks before the GFC, and the performance of acquiring banks deteriorated after takeovers. This evidence is different from the existing average evidence on large samples of takeovers among banks of different sizes during normal times. It is helpful for addressing the specific deficiencies of large bank takeovers during financial crises.

Based on the model of the paper, the fundamental condition for disciplinary takeovers to be effective is that stock prices reflect fundamentals. However, due to some key distinguishing characteristics of large banks including information asymmetry, pro-cyclicality, high leverage and "too-big-to-fail" problem, it is difficult for the market to evaluate large banks' performance and stock prices are not a reliable guide for large banks' valuation. As a result, this paper finds that large bank takeovers were often carried out without proper valuation or a long-term view. In addition, the performance of banks is highly correlated making it difficult for the market to distinguish strong banks from weak banks in good times and for strong banks to acquire weak banks in bad times. Moreover, the high probability of bank insolvency in crises because of high leverage makes it better for acquirers to acquire good assets of target banks after these target banks go bankruptcy; therefore, takeovers are sometimes too late to save weak banks. Although governments might intervene by providing support to acquirers for the sake of financial stability, the taxpayers might have to pay for the downside risk of target banks.

It is necessary to acknowledge that there are some important qualifications when these findings are interpreted in a much broader context. First, it cannot use large-sample standard statistical analysis for a small sample study. Second, the short-run results were affected by the GFC and government support during the GFC (Goodhart, 2020; Song, 2020). Third, the banking sector is a regulated industry which operates differently from other sectors, and its business models in market-based systems are different from those in bank-based financial 
systems. Nonetheless, some qualifications can be rectified: First, case studies of this sample can provide rare, direct and detailed insight; second, the financial performance in the long run can minimize the effects of the GFC and government support in the short run.

The rest of the paper proceeds as follows. Section 2 reviews the relevant literature. Section 3 presents a simple model of the disciplinary takeover and its contribution to the literature. Section 4 introduces the data and analyzes the results. Section 5 discusses why large bank takeovers are not effective. Section 6 concludes the paper.

\section{Literature review}

There is an extensive literature on the disciplinary takeover. Some studies argue that a market for takeovers is one mechanism which deals with the agency problem in modern corporations which operate with a shareholder view that accepts shareholder primacy in the UK and US (Manne, 1965). The shareholder primacy means that the vote of shareholders on a takeover offer is the ultimate arbiter of a company's interests (Dine, 2000). Due to the separation of ownership and control, bidders can gain control either by a tender offer or by a proxy fight without interference from the existing managers and board, thus pushing the management to serve shareholders' interests (Fama and Jensen, 1983).

However, it is argued that takeovers can serve as an effective disciplinary mechanism only if the stock market provides an objective valuation of the firm. Some studies do find that stock prices in large and liquid stock markets signal the implications of the corporate internal decisions for net cash flows (Fama, 1970), and the stock market is efficient in the weak and semi-strong forms but not the strong form (Miller, 1994; Brealey et al., 2020). However, Shiller (2016) argues that there is evidence of speculative bubbles in which stock prices deviate from fundamentals for a long period due to irrational exuberance.

Empirical studies on the value created in takeovers provide some inconclusive evidence. Although takeovers are found, on average, to reduce shareholder returns of acquiring firms (Malmendier et al., 2018), the evidence on the operating performance of takeovers is mixed (Meeks, 1977; Healy et al., 1992; Malmendier et al., 2018; Song and Meeks, 2020).

On bank takeovers, the general finding is that they can generate operating efficiency gains (DeYoung et al., 2009). For example, weak and inefficient banks are more likely to be the targets of takeovers (DeYoung et al., 2009; Kowalik et al., 2015). However, the effect of takeovers on returns to shareholders of acquiring banks is inconclusive (DeYoung et al., 2009). Moreover, some studies find that the potential role of large bank takeovers has been weakened by banks' regulation, capital structure, size, valuation difficulties and remuneration packages (e.g. De Haan and Vlahu, 2016). This paper contributes new evidence to this strand of literature by investigating the performance of large bank takeovers during the GFC and the impact of some key distinguishing characteristics of large banks.

There is also a large body of literature investigating takeovers driven by other factors rather than corporate governance. For example, some papers develop models to analyze takeover activities based on the assumption of misevaluation of stock market participants (e.g. Shleifer and Vishny, 2003). However, their models cannot be used to evaluate the effectiveness of disciplinary takeovers because the fundamental condition of the effective market for corporate control is efficient market. Therefore, this paper develops a model based on the EMH. However, this model can also be used as a benchmark to investigate takeovers if the market is inefficient.

\section{A simple model of an effective market for corporate control}

To discuss the effectiveness of the market for corporate control, a simple model is developed to illustrate the disciplinary takeover.

Assume there are two firms, Firm 1 and Firm 2 in the same sector, with total assets being $A 1$ and $A 2$, equity being $E 1$ and $E 2$, total debt being $D 1$ and $D 2$, return on equity being ROE1 and ROE2, return on total assets being ROA1 and ROA2, cost of debt being Rd1 and Rd2, and 
JCMS 6,1

stock market valuation per unit of equity being $\mathrm{SP} 1$ and $\mathrm{SP} 2$ respectively. So $A 1=D 1+E 1$ and $A 2=D 2+E 2$. To simplify the model, assume dollar $(\$)$ is the unit of measurement of value and each unit of equity represents one dollar. Therefore, SP1/1\$ and SP2/1\$ represent Price/Book ratio (PBR) of Firm 1 and Firm 2 respectively. Assume Firm 1 and Firm 2 are solvent, i.e. $E 1>0$ and $E 2>0$, and the stock market is efficient so that SP1 and SP2 are proper valuations of these two firms based on the shareholder view as there is evidence that stock returns do reflect ROE (Chen and Zhang, 2007; Goodhart, 2020). And assume the price/ earnings ratio of Firm 1 is PER1, and Firm 2 is PER2, and the sector is PER, then PER1 $=$ SP1/ROE1 and PER2 $=$ SP2/ROE2.

Assume both firms pay out all earnings as dividends, and $E 1$ and $E 2$ remain the same over time unless there are changes in the value of assets. However, stock prices will reflect ROE, and $\mathrm{ROE}$ will change because of the change in operating performance.

To define a disciplinary takeover, assume that Firm 1 is the efficient firm and Firm 2 is the inefficient firm in terms of ROE. Assume ROE1 > ROE2, therefore, SP1 > SP2 and PBR1 > PBR2. And to simplify the model, assume this difference in efficiency only reflects the difference in ROA rather than leverage (i.e. Debt/Equity $(D / E)$ ) or cost of debt $(\mathrm{Rd})[1]$. Therefore, assume ROA1 > ROA2, D1/E1 $=D 2 / E 2$, and Rd1 $=\mathrm{Rd} 2$.

Assume Firm 1 pays a price $P$ per unit of equity of Firm 2 to acquire Firm 2 [2]. Assume goodwill for the target is $\mathrm{G}$ which comes from the difference between the consideration and the net assets of Firm 2 and $G \geq 0$, then $P \times E 2=E 2+G$. As a result, $(P-1) \times E 2=G$ and $P \geq 1$ as $G \geq 0$ and $E 2>0$ [3].

\subsection{Hypothesis 1}

Assume the market valuation per unit of equity of the merged firm is SPm (or PBRm) in the short run after the announcement of the acquisition, and SPm (or PBRm) depends on the market's expectation about the future performance of the merged firm. Then the effectiveness of the disciplinary takeover depends on whether SPm (or PBRm) generates gains to the shareholders of event firms. Such gains depend on the methods of payment for the acquisition. Acquirers may issue new debt and/or new equity to pay for acquisitions. If the transaction is an all-cash deal, assume Firm 1 pays $P$ using cash from borrowing debt, then the shareholders of Firm 2 will gain $(P-\mathrm{SP} 2) \times E 2$. However, for Firm 1 shareholders, if all units of equity of the merged firm are expected to earn ROEm (E(ROEm) is used to represent the expected value of ROEm) and $\mathrm{E}(\mathrm{ROEm}) \geq \mathrm{ROE} 1$, then $\mathrm{SPm} \geq \mathrm{SP} 1$ which indicates that $\mathrm{PBRm} \geq \mathrm{PBR} 1$, they gain $(\mathrm{SPm}-\mathrm{SP} 1) \times E 1$. Otherwise, they will lose because $(\mathrm{SPm}-\mathrm{SP} 1) \times E 1$ is negative if $\mathrm{E}(\mathrm{ROEm})<\mathrm{ROE} 1$ and $\mathrm{SPm}<\mathrm{SP} 1$, and $\mathrm{PBRm}<\mathrm{PBR} 1$. In this case, the shareholders of Firm 1 bear all the risks of the acquisition in the short run.

However, if the transaction is an all-stock deal, Firm 1 issues shares to exchange the shares of Firm 2, then the results are very different as Firm 2 shareholders are the shareholders of the merged firm. Assume Firm 2 shareholders own $T$ proportion of the shares of the merged firm, then $T$ can be calculated by $T=P \times E 2 /(E 1+P \times E 2)$, and Firm 1 shareholders own $1-T$ proportion of the shares of merged firms, i.e. $1-T=1-P \times E 2 /(E 1+P \times E 2)=E 1 /(E 1+P \times E 2)$. In this case, Firm 2 shareholders gain $T \times \mathrm{SPm} \times(E 1+P \times E 2)-\mathrm{SP} 2 \times E 2=\mathrm{SPm} \times P \times E 2-\mathrm{SP} 2$ $\times E 2=(\mathrm{SPm} \times P-\mathrm{SP} 2) \times E 2$. So if $\mathrm{SPm} \times P-\mathrm{SP} 2>=0$, i.e. $\mathrm{SPm} \geq \mathrm{SP} 2 / P$, then Firm 2 shareholders gain. As $P \geq 1$, SPm can be less than SP2 for Firm 2 shareholders to gain.

Firm 1 shareholders gain $(\mathrm{SPm}-\mathrm{SP} 1) \times E 1$ as the units of equity remain the same for them [4]. As long as $\mathrm{E}(\mathrm{ROEm}) \geq \mathrm{ROE} 1$, and therefore, $\mathrm{SPm} \geq \mathrm{SP1}$ which indicates that $\mathrm{PBRm} \geq \mathrm{PBR}$, Firm 1 shareholders gain. Firm 2 shareholders also gain as SP1 $>$ SP2.

Accordingly, one hypothesis for the acquiring firm in the short run in terms of stock market performance (PBR) can be developed:

H1. The market for corporate control is effective in the short run if PBRm $\geq P B R 1$ 
However, it is difficult to evaluate whether the market for corporate control is effective in terms of operating performance in the short run. This is because there is no reliable data for $\mathrm{E}(\mathrm{ROEm})$. As a result, it is also difficult to use the expected price/earnings ratio of the merged firm $(\mathrm{E}(\mathrm{PERm}))$ as a measure for stock market performance in the short run. However, in the long run, both ROE and PER of the merged firms can be observed and they could be used to evaluate whether the market for corporate control is effective.

\subsection{Hypotheses 2 and 3}

Large US bank takeovers in 2008

To analyze the returns to shareholders in the long run, it is necessary to define what conditions make the takeover successful. Assume that in the long run, all units of equity of the merged firm earn ROEmf and the market valuation per unit of equity of the merged firm is SPmf (or PBRmf), and return on assets is ROAmf. Then for a disciplinary takeover to be successful due to the improvement of corporate governance of Firm 2, all considerations paid by Firm 1 to Firm 2 shareholders (including $E 2+G$ ) should earn no less than ROE1, all units of equity of the merged firm should earn ROEmf $\geq$ ROE1 and the stock price should be SPmf $\geq$ SP1 which indicates that PBRmf $\geq$ PBR1.

The returns to Firm 2 shareholders in the long run also depend on the methods of payment for the acquisition. If Firm 1 pays $P$ using cash, then the shareholders of Firm 2 will gain $(P-$ $\mathrm{SP} 2) \times E 2$ which is the short-term gain. However, if Firm 1 uses shares for acquisition, then Firm 2 shareholders gain $T \times \mathrm{SPmf} \times(E 1+P \times E 2)-\mathrm{SP} 2 \times E 2=(\mathrm{SPmf} \times P-\mathrm{SP} 2) \times$ $E 2$. So if SPmf $\times P-\mathrm{SP} 2 \geq 0$, i.e. SPmf $\geq \mathrm{SP} 2 / P$, then Firm 2 shareholders gain. As $P \geq 1$, SPmf can be less than SP2 for Firm 2 shareholders to gain.

Based on the model, it seems that Firm 1 shareholders may be indifferent between all-cash bids and all-stock bids as the methods of payment do not affect the conditions for them to gain from the acquisition. That is, if $\mathrm{E}(\mathrm{ROEm}) \geq \mathrm{ROE} 1$ in the short run or ROEmf $\geq \mathrm{ROE} 1$ in the long run, then Firm 1 shareholders gain. However, it is easier for the merged firm to realize the expected ROE with all-cash bids which use higher leverage than all-stock bids [5]. Therefore, ROAmf $\geq$ ROA1 should be used as one measure for identifying an effective disciplinary takeover if the impact of leverage on ROEmf is to be controlled for [6].

Accordingly, two hypotheses for the acquiring firm in the long run in terms of both stock market performance and operating performance (ROE and ROA) can be developed:

H2. The market for corporate control is effective in the long run if PBRmf $\geq$ PBR1

H3. The market for corporate control is effective in the long run if ROAmf $\geq$ ROA1 and ROEmf $\geq$ ROE1

\subsection{Hypothesis 4}

As the operating performance of event banks in the long run can be affected by the general economic and sector factors, it is common to use the performance of industry or non-event matching firms to control for such effects. However, the validity of the results depends on the appropriateness of the benchmarks (Meeks, 1977; Healy et al., 1992). As it is difficult to find non-event matching firms for the sample in this paper, the bank sector is used as the control group. In particular, the difference between the ROE of event banks and that of the bank sector is used to measure the change in the operating performance of event banks during the sample period. Accordingly, one more hypothesis for the acquiring firm can be developed:

H4. The market for corporate control is effective in the long run if ROEmf - Sector ROE after merger $\geq$ ROE1 - Sector ROE before merger.

However, it is worth noting that the results for Hypotheses 4 are subject to some qualifications. This is because of the huge difference between large banks and the general bank sector. 
JCMS 6,1

It is difficult to develop a hypothesis for PER. This is because there is no definite prediction about what could happen to PER in the long term after merger. The reason is that PERmf $=$ PBRmf/ROEmf, and both PBRmf and ROEmf are expected to increase if the market for corporate control is effective. Moreover, PER also depends on the discount rate which will change in line with the market risk premium based on the Capital Asset Pricing Model (CAPM).

In summary, if the market for corporate control is effective, both measures of operating performance (ROA and ROE) and stock market performance (PBR) of acquiring firms should improve or at least not deteriorate after takeovers. This is different from the popular method (e.g. Healy et al., 1992) which compares the actual performance of merged firms with the proforma performance of the two combining event firms in years prior to the takeover. Based on the model in this paper, even if the actual performance of merged firms is greater than the proforma performance of the two combining event firms in years prior to the takeover, the acquiring firm can still lose if the actual performance of merged firms is worse than the performance of acquiring firm before the takeover.

This model also suggests that it is necessary to use the change in price book ratio rather than stock price to measure the stock market performance of takeovers. In the model, the book value per unit of equity is assumed to be $\$ 1$ and remains unchanged during the event period. However, the book value per unit of equity will change in practice. Therefore, it is appropriate to use PBR rather than SP to measure shareholders' returns during the event period. However, most literature (e.g. Malmendier et al., 2018) uses change in the stock price during the event period to measure shareholders' returns from takeovers.

In addition, the model is different from the models which assume that mergers are pure financial plays based on the assumption of inefficient market. These pure financial play models predict that the stock price of merged firm will decrease in the long run because of the overvaluation of the acquirer's stock price during the merger period. Their assumption is that there is no performance improvement arising from the merger in the long run (e.g. Shleifer and Vishny, 2003).

\subsection{Hypotheses testing}

To test the hypotheses statistically, the $t$-test for mean and the non-parametric sign test for median are conducted [7]. They report whether the mean and median of performance measures in the post-takeover period deteriorated. The post-takeover performance measure of each year (following Meeks (1977) and Song and Meeks (2020)) is calculated as the difference between the relative value of each year minus the 3-year average of the relative values in the pre-takeover period. The relative value of each year is calculated using the value of 2006 as the basis which is assumed to be 100 . The null hypothesis is that the difference is greater than or equal to zero. As a result, if the $p$-value of the tests is less than or equal to $5 \%$, it can be claimed that the post-takeover performance deteriorates significantly.

\section{Evidence}

\subsection{Data}

During the GFC, there are six large US banks that were targets of acquisitions by other large banks. Table 1 lists three acquiring banks and six target banks involved in these mergers. Only Lehman Brothers failed to be acquired by other US banks. This sample is unique and important because these acquisitions were expected by the US government agencies to contain the systemic crisis, and four of them are top 10 US bank acquisitions in recent years (Adams, 2012). In addition, "The turmoil that followed the failure of Lehman Brothers in September 2008 has indeed led governments to commit to an unconditional support of any troubled financial institution whose failure might create major disruptions" 


\begin{tabular}{|c|c|c|c|c|c|c|}
\hline Acquirers & Targets & $\begin{array}{l}\text { Method of } \\
\text { payment }\end{array}$ & $\begin{array}{l}\text { Announcement } \\
\text { date }\end{array}$ & $\begin{array}{l}\text { Government } \\
\text { support (2) }\end{array}$ & $\begin{array}{l}\text { Deal agreed } \\
\text { voluntarily (3) }\end{array}$ & $\begin{array}{l}\text { Large US bank } \\
\text { takeovers in }\end{array}$ \\
\hline $\begin{array}{l}\text { Successful } \\
\text { merger }\end{array}$ & & & & & & \\
\hline $\begin{array}{l}\text { JPMorgan } \\
\text { Chase (JPM) }\end{array}$ & $\begin{array}{l}\text { Bear Stearns } \\
\text { (BSC) }\end{array}$ & All stock & Mar-08 & Yes & No & 39 \\
\hline $\begin{array}{l}\text { JPMorgan } \\
\text { Chase (JPM) }\end{array}$ & $\begin{array}{l}\text { Washington } \\
\text { Mutual (WAMU) }\end{array}$ & $\begin{array}{l}\text { Issue new } \\
\text { stocks (1) }\end{array}$ & Sep-08 & No & Yes & \\
\hline $\begin{array}{l}\text { Bank of } \\
\text { America (BAC) }\end{array}$ & $\begin{array}{l}\text { Merrill Lynch } \\
\text { (MER) }\end{array}$ & All stock & Sep-08 & No & Yes & \\
\hline $\begin{array}{l}\text { Bank of } \\
\text { America (BAC) }\end{array}$ & $\begin{array}{l}\text { Countrywide } \\
\text { (CFC) }\end{array}$ & All stock & Jan-08 & No & Yes & \\
\hline $\begin{array}{l}\text { Wells Fargo } \\
\text { (WFC) } \\
\text { Failed merger } \\
\text { attempts }\end{array}$ & Wachovia (WB) & All stock & Oct-08 & No & Yes & \\
\hline $\begin{array}{l}\text { Bank of } \\
\text { America (BAC) }\end{array}$ & $\begin{array}{l}\text { Lehman Brothers } \\
\text { (LEH) }\end{array}$ & & Sep-08 & No & No & \\
\hline
\end{tabular}

Note(s): (1) New stocks were issued to raise cash to pay for the acquisition. All other acquisitions are stock for stock deals

(2) "Government support" indicates that there was government support for the deal on the event day

(3) "Deal agreed voluntarily" indicates that deal agreed with no government support

Table 1.

Source(s): Financial Commission (2011), Annual reports of acquiring banks

(Freixas and Rochet, 2013, p. 38). Moreover, the sample is selected because these banks are systematically important banks (Alvarez, 2010; Financial Commission, 2011; Song, 2014; FSB, 2020), and Gomez (2015) found that such takeovers may increase "the likelihood of a future systemic failure when bankers are impatient or when risk taking profits are high" (p. 46).

Moreover, all acquisitions were private deals that were agreed voluntarily and approved by shareholders without government support except for the acquisition of Bear Stearns by JP Morgan Chase (see Table 1). This indicates that these deals should have been driven mainly by market behavior rather than government intervention (Alvarez, 2010), and they should have been properly valued and expected by bank management to create value for shareholders in the long run. Therefore, their long-term financial performance should truly reveal the efficiency of large bank takeovers.

The sample period is from three years before the event year 2008 to seven years after 2008 . This is in line with most empirical literature on mergers. However, the acquiring company in a merger always has difficulty in terms of performance for the first few years, and the merger could be fully digested beyond 10-15 years. The paper looks at up to 7 years after the merger due to two main factors: first, it is difficult to control for the impact of many other important corporate events on the performance of the acquiring companies over a long period of time after merger; second, there is not enough data [8].

Company financial data is hand-collected from annual reports of event banks; USD Libor data is collected from https://fred.stlouisfed.org, PER and ROE data of the bank sector is collected from http://www.damodaran.com and stock price data is collected from Yahoo Finance.

\subsection{Results}

4.2.1 The performance of event banks before takeover. Before the GFC started in the second half of 2007, the performance of target banks was close to that of acquiring banks in terms of 
JCMS 6,1

both operating performance (ROE and ROA) and stock market performance (PER and PBR) (see Table 2). It is only at the end of 2007, half of six target banks were performing much worse than acquiring banks. Lehman Brothers, Bear Stearns and Wachovia were performing relatively well when the GFC started.

However, investment banks (i.e. Lehman Brothers, Bear Stearns and Merrill Lynch) were highly leveraged than other banks. Table 2 reports that for these banks, equity over total assets ratios (E/A) were around $5 \%$ or less whereas for other banks these ratios were around $7 \%$ or above. As their ROAs were very close to those of other banks, their relatively higher ROEs came from higher leverage. However, their PERs and PBRs were close to those of other banks in 2005 and 2006, indicating that the market did not realize the higher risk of these investment banks that could arise from their higher leverage. In 2007, PBRs also suggest that the market was confident in these banks.

4.2.2 The performance of acquirers after takeover. Most of the performance measures deteriorate in the post-merger years. ROE, ROA and PBR are significantly worse for all banks: the sign test and $t$-test report that all $p$-values are less than $5 \%$ (see Tables 3 and 4 ), which indicates that the market for corporate control is not effective in the long run according to Hypotheses 2 and 3. And PBR in 2008 was negative for all event banks, which indicates that the market for corporate control is not effective in the short run according to Hypothesis 1.

However, relative to the bank sector, the performance of ROE is mixed (see Table 3). But this is expected as discussed in Section 3. The $t$ tests show that Bank of America and Wells Fargo performed significantly worse and the sign test shows that Bank of America performed significantly worse. But JPMorgan Chase performed much better which may be

\begin{tabular}{|c|c|c|c|c|c|c|c|c|c|}
\hline & & Acquire & & & & & & & \\
\hline & JPM & BAC & WFC & $\mathrm{CFC}$ & WB & WAMU & BSC & MER & LEH \\
\hline$R O E(\%)$ & & & & & & & & & \\
\hline 2005 & 8.0 & 16.5 & 19.6 & 22.7 & 14.1 & 14.9 & 16.5 & 15.0 & 21.6 \\
\hline 2006 & 13.0 & 16.3 & 19.5 & 18.8 & 14.4 & 13.5 & 19.1 & 20.1 & 23.4 \\
\hline 2007 & 13.0 & 11.1 & 17.1 & -4.6 & 9.0 & -0.4 & 1.8 & -33.0 & 20.8 \\
\hline PER (\%) & & & & & & & & & \\
\hline 2005 & 16.9 & 11.5 & 14.0 & 8.3 & 12.6 & 11.7 & 10.8 & 13.1 & 11.6 \\
\hline 2006 & 12.1 & 11.7 & 14.4 & 9.9 & 12.3 & 12.5 & 10.7 & 12.3 & 10.8 \\
\hline 2007 & 10.1 & 12.5 & 12.7 & -4.4 & 11.7 & -113.4 & 65.6 & -5.5 & 8.6 \\
\hline$P B R$ & & & & & & & & & \\
\hline 2005 & 1.3 & 1.8 & 2.6 & 1.6 & 1.7 & 1.6 & 1.6 & 1.9 & 2.2 \\
\hline 2006 & 1.4 & 1.8 & 2.6 & 1.8 & 1.6 & 1.6 & 1.8 & 2.3 & 2.2 \\
\hline 2007 & 1.2 & 1.3 & 2.1 & 0.2 & 1.0 & 0.6 & 1.2 & 1.8 & 1.6 \\
\hline$E / A(\%)$ & & & & & & & & & \\
\hline 2005 & 8.9 & 7.9 & 8.8 & 7.3 & 9.0 & 7.9 & 3.8 & 5.2 & 4.1 \\
\hline 2006 & 8.6 & 9.3 & 8.9 & 7.2 & 7.7 & 7.8 & 3.5 & 4.6 & 3.8 \\
\hline 2007 & 7.9 & 8.6 & 9.0 & 6.9 & 9.0 & 7.5 & 3.0 & 3.1 & 3.3 \\
\hline$R O A(\%)$ & & & & & & & & & \\
\hline 2005 & 4.8 & 5.5 & 5.9 & 5.9 & 5.4 & 5.4 & 5.0 & 5.1 & 5.2 \\
\hline 2006 & 6.1 & 6.5 & 6.7 & 6.4 & 6.2 & 6.1 & 6.0 & 6.2 & 6.2 \\
\hline 2007 & 6.3 & 6.2 & 6.7 & 5.0 & 6.0 & 5.2 & 5.6 & 4.5 & 6.2 \\
\hline
\end{tabular}

Table 2.

The performance of large US banks before the acquisitions
Note(s): Data are hand-collected from annual reports of each bank ROA (\%) is calculated using ROE, E/A and borrowing cost of banks which is the 3 month USD Libor Negative numbers are not meaningful but indicating that banks have losses rather than positive earnings $\mathrm{E} / \mathrm{A}(\%)$ is equity over total assets ratio 


\begin{tabular}{|c|c|c|c|c|c|c|c|}
\hline \multirow[b]{2}{*}{ Year } & \multicolumn{3}{|c|}{$\operatorname{ROE}(\%)$} & \multicolumn{3}{|c|}{ ROA $(\%)$} & \multirow{2}{*}{$\begin{array}{l}\text { Large US bank } \\
\text { takeovers in }\end{array}$} \\
\hline & JPM & $\mathrm{BAC}$ & WFC & JPM & BAC & WFC & \\
\hline 2008 & -56.41 & -78.80 & -71.48 & -57.66 & -61.68 & -61.67 & \\
\hline 2009 & -41.03 & -89.94 & -45.41 & -76.76 & -84.77 & -77.83 & \\
\hline 2010 & -10.26 & -89.97 & -43.10 & -68.48 & -82.26 & -70.98 & \\
\hline 2011 & -2.56 & -89.61 & -34.90 & -62.82 & -77.99 & -63.43 & \\
\hline 2012 & -2.56 & -82.05 & -29.68 & -70.78 & -84.20 & -69.13 & 41 \\
\hline 2013 & -17.95 & -61.46 & -24.97 & -73.02 & -77.89 & -67.56 & \\
\hline 2014 & -10.26 & -79.41 & -27.32 & -71.14 & -82.78 & -68.84 & \\
\hline 2015 & -2.56 & -51.38 & -31.47 & -66.53 & -73.77 & -69.92 & \\
\hline Number of observations & & 8 & 8 & 8 & 8 & 8 & \\
\hline Median & -10.26 & -80.73 & -33.19 & -69.63 & -80.12 & -68.98 & \\
\hline Sign test (one-tailed $p$-value) & 0.00 & 0.00 & 0.00 & 0.00 & 0.00 & 0.00 & \\
\hline Mean & -17.95 & -77.83 & -38.54 & -68.40 & -78.17 & -68.67 & \\
\hline Mean test (one-tailed $p$-value) & 0.02 & 0.00 & 0.00 & 0.00 & 0.00 & 0.00 & \\
\hline \multicolumn{8}{|l|}{ ROE $(\%)$-sector ROE $(\%)$} \\
\hline 2008 & & 7.95 & & 2.47 & & 1.33 & \\
\hline 2009 & & 4.55 & & -4.75 & & 1.02 & \\
\hline 2010 & & 5.01 & & -8.29 & & -2.07 & \\
\hline 2011 & & 4.63 & & -9.61 & & -1.85 & \\
\hline 2012 & & -2.94 & & -15.95 & & -8.40 & \\
\hline 2013 & & 1.88 & & -5.78 & & -0.66 & \\
\hline 2014 & & 1.17 & & -10.41 & & -2.83 & \\
\hline 2015 & & 2.63 & & -5.39 & & -3.18 & \\
\hline Number of observations & & 8 & & 8 & & 8 & \\
\hline Median & & 3.59 & & -7.04 & & -1.96 & \\
\hline Sign test (one-tailed $p$-value) & & 1.00 & & 0.04 & & 0.14 & \\
\hline Mean & & 3.11 & & -7.22 & & -2.08 & \\
\hline Mean test (one-tailed $p$-value) & & 0.99 & & 0.00 & & 0.05 & \\
\hline \multicolumn{8}{|c|}{$\begin{array}{l}\text { Note(s): The operating performance of each year is the relative value of each year minus the } 3 \text {-year average of } \\
\text { the relative values before takeover. The relative value of each year is calculated using the value of } 2006 \text {, which } \\
\text { is assumed to be 100, as the basis. The original ROE of bank sector is collected from http://www.damodaran. } \\
\text { com. Other data is hand-collected from annual reports of each bank. The original ROA }(\%) \text { is calculated using } \\
\text { ROE, E/A and borrowing cost of banks which is the } 3 \text { month USD Libor. The null hypothesis for the sign test } \\
\text { and } t \text {-test is that the median and mean of operating performance measure are greater than or equal to zero } \\
\text { respectively }\end{array}$} \\
\hline
\end{tabular}

due to its much lower E/A ratios (see Table 5). Therefore, there is no consistent evidence supporting Hypothesis 4.

To demonstrate why these measures are important, the results in terms of shareholder returns which are a popular measure in the literature are reported here for comparison. Acquiring banks performed worse in the event year 2008 in terms of total cumulative shareholder returns (TCSRs) (see Table 4). However, statistical tests report that only Bank of America performed worse in the post-takeover years. One reason could be that the book value per share of Bank of America has declined significantly while those of the other two banks have increased significantly since the event year 2008 (see Table 5). Therefore, it is not appropriate to use the TCSR to measure the actual returns of shareholders because it does not control for the impact of the book value per share.

Overall, the evidence indicates that large bank takeovers are ineffective. First, the market did not realize that target banks were significantly weaker than acquirers prior to the GFC. Second, acquirers performed worse in the post-merger period than in the pre-merger period. 
JCMS

6,1

\begin{tabular}{lccrrrr}
\hline & \multicolumn{3}{c}{ PBR (\%) } & \multicolumn{3}{c}{ Total cumulative shareholder } \\
Year & JPM & BAC & WFC & JPM & BAC & WFC \\
\hline 2008 & -30.30 & -62.77 & -23.23 & -21.33 & -57.88 & -1.16 \\
2009 & -18.34 & -51.97 & -41.46 & 2.48 & -55.88 & -6.16 \\
2010 & -22.45 & -55.62 & -40.30 & 4.59 & -58.88 & 7.84 \\
2011 & -41.21 & -75.58 & -50.20 & -14.62 & -75.88 & -2.16 \\
2012 & -31.22 & -59.06 & -45.70 & 13.17 & -62.36 & 22.84 \\
2013 & -14.54 & -49.15 & -34.12 & 51.37 & -53.66 & 64.84 \\
2014 & -14.65 & -44.29 & -27.90 & 74.99 & -48.15 & 101.84 \\
2015 & -15.07 & -49.44 & -31.48 & 78.51 & -50.18 & 105.84 \\
Number of observations & 8 & 8 & 8 & 8 & 8 & 8 \\
Median & -20.40 & -53.79 & -37.21 & 8.88 & -56.88 & 15.34 \\
Sign test (one-tailed $p$-value) & 0.00 & 0.00 & 0.00 & 0.96 & 0.00 & 0.86 \\
Mean & -23.47 & -55.98 & -36.80 & 23.65 & -57.86 & 36.72 \\
Mean test (one-tailed $p$-value) & 0.00 & 0.00 & 0.00 & 0.93 & 0.00 & 0.97
\end{tabular}

Table 4.

Stock market performance of acquiring banks after acquisitions

Note(s): The stock market performance of each year is the relative value of each year minus the 3-year average of the relative values before takeover. The relative value of each year is calculated using the value of 2006 , which is assumed to be 100, as the basis. Data is hand-collected from annual reports of each bank. The stock market return assumes that all dividends are reinvested during the years. The null hypothesis for the sign test and $t$-test is that the median and mean of stock market performance measure are greater than or equal to zero respectively

\begin{tabular}{lrrrrrr}
\hline & \multicolumn{3}{c}{ Book value per share } & \multicolumn{3}{c}{ Equity over total assets ratio } \\
Year & JPM & BAC & WFC & JPM & BAC & WFC \\
\hline 2005 & 91.81 & 85.25 & 89.31 & 103.49 & 84.79 & 98.87 \\
2006 & 100.00 & 100.00 & 100.00 & 100.00 & 100.00 & 100.00 \\
2007 & 109.39 & 108.05 & 106.48 & 91.86 & 92.34 & 101.80 \\
2008 & 108.07 & 93.50 & 119.01 & 89.53 & 105.07 & 92.12 \\
2009 & 119.22 & 72.32 & 147.61 & 94.19 & 112.30 & 72.18 \\
2010 & 128.67 & 70.67 & 165.73 & 96.51 & 108.74 & 103.27 \\
2011 & 139.07 & 67.64 & 181.58 & 94.19 & 116.61 & 111.60 \\
2012 & 153.03 & 68.15 & 203.68 & 101.16 & 115.64 & 116.67 \\
2013 & 158.95 & 69.73 & 217.24 & 101.16 & 119.42 & 114.53 \\
2014 & 170.34 & 71.78 & 237.21 & 104.65 & 124.81 & 111.04 \\
2015 & 180.75 & 75.89 & 248.93 & 122.09 & 128.91 & 108.33
\end{tabular}

Table 5.

Book value per share and equity over total assets $(\mathrm{E} / \mathrm{A})$ ratio of acquiring banks
Note(s): Data is hand-collected from annual reports of each bank

The value in 2006 is assumed to be 100 which is the basis for calculating relative value of other years

\section{Why large bank takeovers are not effective}

The effectiveness of large bank takeovers is significantly affected by some key distinguishing characteristics of large banks. These characteristics include information asymmetry, pro-cyclicality, high leverage and "too-big-to-fail" problem. The effects of these factors are discussed in detail.

\subsection{Information asymmetry}

Information asymmetry affects the stock market efficiency. Stock prices of large banks cannot be a reliable guide for valuation based on which the market for corporate control works effectively. This is because it is very difficult for the stock market to estimate the value 
of large banks properly based on ROE and other available information. To mitigate information asymmetry, fair value accounting is applied to measure a significant portion of the assets of large banks to increase consistency and comparability of financial reporting (Song, 2014). However, judgment is required to determine fair value if there is no observable data other than that from distressed sales, which could erode the market's confidence in the valuation of large banks' assets.

Indeed, there is evidence that fair value accounting accentuated fire sales of assets and contributed significantly to the GFC (Song, 2020). As a result, it was very difficult to reach agreements on takeovers of large banks during the GFC. For example, in the case of Lehman Brothers, there was significant difference in the valuation of the bank's assets in September 2008. Even though Lehman Brothers insisted that it was solvent, Bank of America CEO Ken Lewis argued that Lehman Brothers could be overvalued by $\$ 60$ to $\$ 70$ billion, and he could agree to acquire Lehman Brothers only if there was government support (Financial Commission, 2011). In the case of Countrywide, Bank of America paid approximately $\$ 4$ billion for the acquisition, but probably lost $\$ 40$ billion due to write-downs, legal expenses and settlements because of troubles of Countrywide (Protess, 2012).

Indeed, the inevitable information asymmetry can be the real flaw in the shareholder view (Miller, 1994). This is because management cannot disclose all information of the proposed projects for fear of competition. For example, the aim of Bank of America's acquisition of Merrill Lynch was to create a company unrivalled in its breadth of financial services and global reach. But Bank of America was charged by the SEC "with failing to disclose about $\$ 9.5$ billion of known and expected Merrill Lynch losses before the December 5 shareholder vote" which "deprives shareholders of material information that was critical to their ability to fairly evaluate the merger" (Financial Commission, 2011, p. 383).

\subsection{Pro-cyclicality}

Pro-cyclicality also affects the stock market efficiency. Banks are pro-cyclical because their credit supply to the economy depends on the business cycle. This creates the pro-cyclicality of banks' stock prices because stock prices are affected by earnings forecasts which rely on the quality of financial reporting (Greenspan, 2002), and financial reporting is pro-cyclical due to fair value accounting in addition to loan loss provisions [9] (Laeven and Huizinga, 2019; Song, 2014; Wheeler, 2019).

Indeed, the valuation of banks is pro-cyclical. The stock return of financial sector performs better in the early cycle and performs worse in the recession (Emsbo-Mattingly and Hofschire, 2017). This pro-cyclicality means that stock prices cannot be a reliable indicator for banks' operating performance and risk (FSA, 2009), and the performance of most banks is highly correlated. During booms most banks perform well and during crises most banks perform poorly, making it difficult to distinguish strong banks from weak banks as their businesses are complex and diversified (Yang and Tsatsaronis, 2012), which is documented in Section 4. Moreover, after the GFC, large banks' business models are becoming more similar (Roengpitya et al., 2014), and this could make the correlation of the performance of large banks more significant.

As a result, during crises, there are few large banks which are strong enough to acquire weak banks. For example, during the GFC, JP Morgan was "the only candidate with the size and stature to make a credible offer with $48 \mathrm{~h}$ " to Bear Stearns (Financial Commission, 2011, p. 290), and it also was the only bidder for Washington Mutual. However, there was no buyer for Lehman Brothers as Bank of America bought Merrill Lynch and Barclays withdrew (Financial Commission, 2011).

In addition, pro-cyclicality and trust erosion due to information asymmetry promote shorttermism in the equity market (Wehinger, 2011). Bank shareholders and management make decisions for short-term gains at the expense of the long-term interests of companies. 
JCMS

6,1

Moreover, the pressure from the real and the perceived threat of takeover also help prohibit CEOs from taking a long view (Charkham, 1993). For example, although Citigroup was a troubled bank, it offered to acquire Wachovia with US government support. If Wells Fargo had not won the bidding war, "Citigroup would have had to have been bailout again" (Financial Commission, 2011, p. 370).

\subsection{High leverage}

Banks' high leverage increases the probability of bank insolvency in crises. This reduces the willingness of a strong bank to buy a weak bank that could be insolvent. In the model of Section 3, if $E 2$ of Firm 2 is negative, it is hard for Firm 1 to justify why it will pay a price $P$ to acquire Firm 2 as Firm 1 will assume more debt than the value of assets from the acquisition. The best strategy for Firm 1 is to buy the good assets from Firm 2 after Firm 2 goes bankrupt as Firm 2's assets will be selling at the prevailing depressed market rate, and the shareholders and creditors of Firm 2 pay for the losses made by Firm 2.

Indeed, Lehman Brothers' bankruptcy in 2008 illustrates this failure of the market of corporate control for large banks. One key reason that the acquisition efforts to rescue Lehman Brothers failed is that Lehman Brothers was thought to be insolvent by the Fed, US Treasury, SEC and some bankers involved in the acquisition efforts (Financial Commission, 2011). The US government officials thought it needed more than $\$ 12$ billion to keep Lehman Brothers alive as a going concern, however, Barclays bought the healthiest assets of the bank at $\$ 1.75$ billion after it filed for bankruptcy protection (Schaefer, 2010).

\subsection{Too-big-to-fail problem}

Governments often support large banks for the sake of financial stability, and this generates the market perception of "too-big-to-fail." With such a perception, the market has no incentive to monitor the bank risk which makes the disciplinary role of takeovers ineffective. Indeed, there is evidence that the market has positive stock price reactions to too-big-to-fail banks (Allen et al., 2018).

When governments support large bank takeovers during the crises, the function of corporate control can be further eroded. This is because valuation of target banks could be compromised as acquiring banks can benefit from these takeovers at the expense of taxpayers if the actual performance of target banks is worse than expected by the government. Acquiring banks obtain a call option with little cost as the government guarantees the liability of target banks by acquiring assets of target banks. Indeed, JP Morgan Chase's acquisition of Bear Stearns was supported by the US Fed which agreed to bear any losses up to $\$ 28.82$ billion; however, JP Morgan Chase only bore the risk of the first $\$ 1.15$ billion of losses (Financial Commission, 2011).

Moreover, government intervention may push large banks into "a shotgun wedding" without sufficient information disclosure to the public when they are in difficulty. For example, in the case of Lehman Brothers during the GFC, one option that a Fed official put forward to resolve the bank was to "find a buyer at any price" (Financial Commission, 2011, p. 331).

\section{Conclusions}

The paper finds that takeovers have not played the role of the market for corporate control for large banks effectively. Based on a general model of the disciplinary takeover, the paper investigates the performance of systemically important banks' takeovers in the US during the GFC. The evidence suggests that the market was ineffective as it did not distinguish strong banks from weak banks before the GFC. Moreover, acquiring banks failed to improve their 
performance after takeover. It is important to emphasize that there are limitations of these results which are common to small sample studies and the GFC could have a significant effect on them in the short run.

Some key distinguishing characteristics of large banks have contributed to the deficiencies of large bank takeovers. First, information asymmetry makes it difficult for event banks to evaluate takeovers. Second, pro-cyclicality enhances the correlation of performance of banks. In addition, pro-cyclicality, together with information asymmetry, promotes short-termism which prevents bank management from holding a long-term view. takeovers in 2008 Third, banks' high leverage increases the probability of bank insolvency during crises which makes takeovers urgent but difficult to implement. Finally, government support of takeovers generates the problem of too-big-to-fail which often benefits banks at the expense of the taxpayer.

Therefore, it is important to deal with these deficiencies. Indeed, some important new measures have been developed. For example, banks are required to employ a "bail-in" strategy, hold a long-term view, strengthen capital and liquidity positions and adopt the EL models for financial reporting. Further research is needed to investigate whether these measures can rectify the deficiencies of the takeover market for large banks.

\section{Notes}

1. This assumption is made because ROE is affected by ROA, Rd and D/E based on the formula $\mathrm{ROE}=\mathrm{ROA}+(\mathrm{ROA}-\mathrm{Rd}) *(D / E)$.

2. Assume the accounting method is the acquisition (purchase) method as the pooling of interests method was eliminated since 2001 by FASB and 2004 by IASB.

3. In the model, assume $G \geq 0$ in normal conditions. However, when a target firm is on a forced sale, it is possible that $G \leq 0$. For example, JP Morgan Chase's acquisition of Bear Stearns generated negative goodwill $\$ 8.9$ billion as $\$ 1.4$ billion was paid by JP Morgan Chase to acquire $\$ 10.3$ billion net assets. But such negative goodwill is required to be recognized in earnings as of the acquisition date by accounting standards.

4. This result is the same as that computed using this formula $(1-T) \times \mathrm{SPm} \times(E 1+P \times E 2)$ $-\mathrm{SP} 1 \times E 1$.

5. This is because $\mathrm{ROE}=\mathrm{ROA}+(\mathrm{ROA}-\mathrm{Rd}) *(D / E)$. For the merged firm with all cash-bids, $\mathrm{ROEmf}=\mathrm{ROAmf}+(\mathrm{ROAmf}-\mathrm{Rd} 1) \times((D 1+D 2+E 2+G) / E 1)$. However, with all stock-bids, $\mathrm{ROEmf}=\mathrm{ROAmf}+(\mathrm{ROAmf}-\mathrm{Rd} 1) \times((D 1+D 2) /(E 1+E 2+G))$. Therefore, all-cash bids use higher leverage than all-stock bids.

6. Indeed, there is evidence that firms achieve a higher ROE by borrowing money to buy back outstanding equity (Goodhart, 2020).

7. As the sample size is small, both parametric and non-parametric methods are used, which follows the general practice in the literature.

8. Thanks to one referee for this issue.

9. Loan loss provisions used the incurred loss approach which was replaced with expected loss (EL) models by IFRS 9 in 2014 and by FASB in 2016 .

\section{References}

Adams, R.M. (2012), Consolidation and Merger Activity in the United States Banking Industry from 2000 through 2010, Finance and Economics Discussion Series, pp. 2012-2051.

Allen, K.D., Cyree, K.B., Whitledge, M.D. and Winters, D.B. (2018), “An event study analysis of too-bigto-fail after the Dodd-Frank act: who is too big to fail?", Journal of Economics and Business, Vol. 98, pp. 19-31. 
JCMS 6,1

Alvarez, S.G. (2010), "The acquisition of Wachovia corporation by wells Fargo \& company", available at: https://www.federalreserve.gov/newsevents/testimony/alvarez20100901a.htm.

Brealey, R.A., Myers, S.C. and Allen, F. (2020), Principles of Corporate Finance, 13th ed., McGraw-Hill/ Irwin, New York, NY.

Charkham, J. (1993), "The Bank and corporate governance: past, present and future”, Bank of England Quarterly Bulletin, August, pp. 388-392.

Chen, P. and Zhang, G. (2007), "How do accounting variables explain stock price movements? Theory and evidence", Journal of Accounting and Economics, Vol. 43, pp. 219-244.

De Haan, J. and Vlahu, R. (2016), “Corporate governance of banks: a survey”, Journal of Economic Surveys, Vol. 30 No. 2, pp. 228-277.

DeYoung, R., Evanoff, D.D. and Molyneux, P. (2009), "Mergers and acquisitions of financial institutions: a review of the post-2000 literature", Journal of Financial Services Research, Vol. 36, pp. 87-110.

Dine, J. (2000), The Governance of Corporate Groups, Cambridge University Press, Cambridge.

Emsbo-Mattingly, L. and Hofschire, D. (2017), "The business cycle approach to asset allocation", available at: https://institutional.fidelity.com/app/proxy/content?literatureURL=/953042.PDF.

Fama, E. (1970), "Efficient capital markets: a review of theory and empirical work", Journal of Finance, Vol. 25 No. 2, pp. 383-417.

Fama, E.F. and Jensen, M.C. (1983), "Separation of ownership and control", Journal of Law and Economics, Vols 26-2, June, pp. 301-325.

Financial Commission (2011), The Financial Crisis Inquiry Report, 27 Jan.

Freixas, X. and Rochet, J.C. (2013), “Taming systemically important financial institutions”, Journal of Money, Credit and Banking, Blackwell Publishing, Vol. 45 No. s1, pp. 37-58.

FSA (2009), "The Turner Review: a regulatory response to the global banking crisis", March 2009, available at: http://www.fsa.gov.uk/pubs/other/turner_review.pdf.

FSA (2011), "The failure of the royal Bank of Scotland", available at: http://www.fsa.gov.uk/pubs/ other/rbs.pdf.

FSB (2020), “2020 list of global systemically important banks (G-SIBs)”, available at: https://www.fsb. org/wp-content/uploads/P111120.pdf.

Gomez, F. (2015), "Failed bank takeovers and financial stability", Journal of Financial Stability, Vol. 16, pp. $45-58$.

Goodhart, C. (2020), "Central bank policies before and after the crisis", Journal of Banking, Finance and Sustainable Development, Vol. 1 No. 1, pp. 33-41.

Greenspan, A. (2002), Corporate Governance, Remarks at the Stern School of Business, New York University, March 26.

Healy, P.M., Palepu, K.G. and Ruback, R.S. (1992), "Does corporate performance improve after mergers?", Journal of Financial Economics, Vol. 31, pp. 135-175.

Inci, A.C., Li, H.C. and McCarthy, J. (2014), "Flight to quality for large financial institutions", Banking and Finance Review, Vol. 6 No. 1, pp. 75-90.

Kowalik, M., Davig, T., Morris, C. and Regehr, K. (2015), "Bank consolidation and merger activity following the crisis", Economic Review, QI, pp. 31-49.

Laeven, L. and Huizinga, H. (2019), The Procyclicality of Banking: Evidence from the Euro Area, CEPR Discussion Paper 13605.

Macskasi, Z. (2016), "Bank mergers and systemic risk", available at: https://www. competitionpolicyinternational.com/wp-content/uploads/2016/12/CPI-Macskasi-final.pdf.

Malmendier, U., Moretti, E. and Peters, F.S. (2018), "Winning by losing: evidence on the long-run effects of mergers", The Review of Financial Studies, Vol. 31 No. 8, pp. 3212-3264. 
Manne, H. (1965), "Mergers and the market for corporate control", Journal of Political Economy, Vol. 73, pp. 110-120.

Meeks, G. (1977), Disappointing Marriage: A Study of the Gains from Merger, Cambridge University Press.

Miller, M.H. (1994), "Is American corporate governance fatally flawed?", Journal of Applied Corporate Finance, Vol. 6 No. 4, pp. 32-39.

Porter, M.E. (1992), “Capital disadvantage: America's falling capital investment system”, Harvard Business Review, Vol. 70 No. 5, pp. 65-82.

Protess, B. (2012), "Tallying the costs of Bank of America's Countrywide nightmare", available at: https://dealbook.nytimes.com/2012/10/25/tallying-the-costs-of-bank-of-americas-countrywidenightmare/?mcubz $=0$.

Roengpitya, R., Tarashev, N. and Tsatsaronis, K. (2014), "Bank business models", BIS Quarterly Review December, pp. 67-77.

Schaefer, S. (2010), Lehman Deal a Sparkler for Barclays’ Diamond, Forbes.7 Sept.

Shiller, R.J. (2016), Irrational Exuberance, 3rd ed., Princeton University Press, Princeton, NJ.

Shleifer, A. and Vishny, R. (2003), "Stock market driven acquisitions", Journal of Financial Economics, Vol. 70, pp. 295-311.

Song, G. (2014), "The pro-cyclical impact of Basel III regulatory capital on bank capital risk", in Batten, J.A. and Wagner, N. (Eds), Risk Management Post Financial Crisis: A Period of Monetary Easing (Contemporary Studies in Economic and Financial Analysis, Emerald Group Publishing Limited, Vol. 96, pp. 59-81.

Song, G. (2020), "The role of fair-value accounting in the global financial crisis: evidence from U.S. global systemically important banks", Journal of Banking, Finance and Sustainable Development, Vol. 1 No. 1, pp. 84-103.

Song, G. and Meeks, G. (2020), "The financial performance of acquired companies in the Chinese stock market", in Amir, A.Z. and Geoff, M. (Eds), Accounting for M\&A: Uses and Abuses of Accounting in Monitoring and Promoting Merger, Routledge, pp. 252-283.

Wehinger, G. (2011), "Fostering long-term investment and economic growth", OECD Journal: Financial Market Trends, Vol. 2011 No. 1, pp. 1-21.

Wheeler, P.B. (2019), "Loan loss accounting and procyclical bank lending: the role of direct regulatory actions", Journal of Accounting and Economics, Vol. 67, pp. 463-495.

Yang, J. and Tsatsaronis, K. (2012), "Bank stock returns, leverage and the business cycle", BIS Quarterly Review March, pp. 45-59.

\section{Corresponding author}

Guoxiang Song can be contacted at: goal2106@gmail.com
Large US bank takeovers in 2008 